\title{
PARTIAL RESISTANCE OF WHEAT (TRITICUM AESTIVUM) TO LEAF RUST (PUCCINIA TRITICINA) IN EGYPT. A. EVALUATION OF SEVEN EGYPTIAN WHEAT CULTIVARS FOR PARTIAL RESISTANCE AGAINST LEAF RUST, UNDER FIELD CONDITIONS.
}

\author{
BOULOT, O.A. and A.A. ALY
}

Plant Pathology Research Institute, ARC, Giza, Egypt.

(Manuscript received 14 April 2014)

\begin{abstract}
Leaf rust is the most prevalent and widespread disease of wheat in Egypt and worldwide. The major obstacle in the control of such disease is the loss of host genetic resistance, as the pathogen evolves into new pathotypes. Therefore, this study was carried out to characterize partial resistance (PR), as a more durable form of resistance in seven locally produced wheat cultivars. From the tested cultivars only four cvs. , Giza 168, Sakha 94, Sakha 95 and sids- 12 proved to have an adequate level of PR, compared to the highly susceptible cvs., sids-1, Gemmeiza-7 and Giza 139. Rust incidence as a final rust severity (FRS\%), rate of disease increase ( $r$-value) and area under disease progress curve (AUDPC), were found to be lower in magnitude in PR cultivars than in the highly susceptible ones under the same field conditions in the two years in concern (2010 and 2011).Partially resistant cultivars were characterized by their high potential to slowdown the incidence and development of leaf rust infection, under favorable field conditions , in contrast to the highly susceptible cultivars. Thus partial resistance to leaf rust in wheat genotypes could be accurately measured, characterized, screened and selected equally well under field conditions by using the most convenient epidemiological parameters, FRS\%, AUDPC and $r$ - value.

Key words : Final rust severity, FRS, adult plant resistance, APR, partial resistance, ,PR.
\end{abstract}

\section{INTRODUCTION}

Leaf rust (Puccinia triticinia Eriks), is among the most common and widespread foliar diseases of wheat in Egypt. It occurs annually in almost all the cultivated wheat varieties, throughout many fields in the country. Moreover, it causes a considerable yield losses (reaching $23 \%$ ) in the susceptible wheat cultivars under suitable environmental conditions, particularly in the northern parts of the Delta region (Nazim et al., 1983). Utilization of resistant cultivars is still an economical, environmentally safe and most effective method for successful disease control via avoiding the sudden occurrence of damaging leaf rust epidemics. However, the major obstacle in the control of wheat leaf rust is the short duration and rapid loss of the host inherited resistance (Nazim et al., 1990 and Sayre et al., 1998). Under field 
conditions in Egypt some of the newly released resistant wheat cultivars were discarded shortly after wide cultivation, because of their high susceptibility to leaf rust, although they were resistant at the time of their release. Nevertheless, many of these cultivars served in agriculture for a long duration, showing an acceptable and high levels of disease resistance during their wide use in agriculture. These cultivars were characterized by their ability to retard and slowdown the development of disease during an epidemic. Consequently, they reduce and restrict the rate of rust progress and minimize the amount of disease in leaf tissue affected, irrespective of their susceptibility to leaf rust in terms of infection type. Such form of resistance has been early defined by Parlevliet, (1976), as a partial resistance (PR) and/or an adult plant resistance (APR), that assumed to be more durable and more stable compared to other forms of resistance (Broers, 1989, Borers and Parlevliet, 1989 and Boulot, 2007).

Partial resistance to wheat leaf rust has been firstly recorded in the Egyptian wheat cultivar, Giza 155, which proved to have an acceptable and adequate level of APR to leaf rust, during its widespread cultivation in the commercial fields in Egypt from 1967 to 1982 (Nazim et al., 1983), After that, some attempts have been made to estimate, characterize and accurately detect PR to rust pathogens, especially leaf rust in some Egyptian wheat cultivars (Nazim et al., 1990, Negm, 2004 and Boulot, 2007).

Although PR to leaf rust ( $P$. triticina) has been early known and recognized in some Egyptian wheat cultivars, its epidemiological nature was not definitely understood and its value was not completely appreciated. Therefore, this type of resistance has been not fully exploited for improving genetic resistance of wheat cultivars against leaf rust, in the national wheat breeding program in Egypt. Hence, the evaluation of some Egyptian wheat cultivars as to the possession of partial resistance to leaf rust was the main objective of the present work.

\section{MATERIALS AND METHODS}

Partial resistance (PR) to leaf rust (Puccinia triticina) in seven Egyptian wheat cultivars was studied at the adult plant stage. The tested wheat cultivars , Sids-1, Giza 168, Sakha 94, Sakha95, Gemmeiza 7, Sids 12, as well as Giza 139 which is being used as a ckeck variety, were grown under field conditions, at El-Nubaria Agric. Res. Station, in the two successive growing seasons, 2009/010 and 2010/011. The experiments were carried out in a randomized complete block design, with four replicates. The grains of the tested cultivars were sown in 6 row plots, each row was 
$3 \mathrm{~m}$ long and $30 \mathrm{~cm}$ apart, where the plot size were $3 \mathrm{~m} \times 3.5 \mathrm{~m}=10.5 \mathrm{~m}^{2}(1 / 400$ Feddan). All plots were surrounded by rust spreader belt, planted with a mixture of the highly susceptible varieties to leaf rust i.e. Thatcher, Giza 139 and Giza 160, to serve as a predominant and continuous spreader source for the disease infection.

Artificial inoculation with a mixture of freshly collected urediniospores of the most prevalent leaf rust reaces and talcum powder in a ratio of $1: 20(\mathrm{v} / \mathrm{v})$ was carried out, to maintain a regular rust inoculum with spores on all spreader plants and generate leaf rust epidemic .

Leaf rust severity percentage, was measured for the seven wheat cultivars, as a percentage of leaf area infected or rusted according to the modified Cobb's scale (Peterson et al., 1948). Rust severity data were recorded starting with the appearance of the first pustule on each of the tested cultivars and continued at 7 days intervals, until the termination of the experiment. Also, final rust severity (FRS $\%$ ) was assessed as a percentage of disease severity for each of the tested wheat varieties, when the highly susceptible variety, Giza 139 was severely rusted and the disease severity reached its maximum and final level (Das et al., 1993).

To estimate more accurately the level of PR or adult plant resistance in the tested wheat cultivars, under field conditions, AUDPC values were calculated for each cultivar by using the equation of ( Pandey et al.,1989) as follow:

$$
\text { AUDPC }=D\left[1 / 2\left(Y_{1}+Y_{k}\right)+\left(Y_{2}+Y_{3}+\ldots . . . Y_{k-1}\right)\right]
$$

where:

D: Days between two consecutive recording (time intervals)

$Y_{1}+Y_{k}$ : Sum of the first and last disease scores.

$Y_{2}+Y_{3}+Y_{K-1}$ : Sum of all in between disease scores.

Rate of leaf rust increase ( $r$-value) as a function of times were also estimated, according to the formula of Van der Plank, (1963) as follows:

$$
r \text {-value }=\frac{1}{t_{2}-t_{1}}\left(\log _{e} \frac{x_{2}}{1-x_{2}}-\log _{\mathrm{e}} \frac{x_{1}}{1-x_{1}}\right)
$$

where:

$\mathrm{x}_{1}=$ the proportion of the susceptible infected tissues (disease severity) at $t_{1}$ date.

$x_{2}=$ the proportion of the susceptible infected tissues (disease severity) at $t_{2}$ date.

$t_{2}-t_{1}=$ is the interval in days between these two dates. 


\section{Statistical analysis :}

The obtained data were statistically analyzed, for each season individually, and the combined analysis of variance over the two seasons was also carried out (Table, 1). Significance of difference among the studied varieties was tested by the analysis of variance (ANOVA) test, as outlined by Snedecor and Cochran, 1967. Mean comparisons for variables were made among genotypes using L.S.D.

Table 1. Analysis of variance for the final rust severity (FRS\%), rate of disease increase ( $r$-value) and area under disease progress curve (AUDPC), combined data from 7 Egyptian wheat varieties evaluated for the level of partial resistance (PR) under field conditions, at El-Nubaria location.

\begin{tabular}{|c|c|c|c|c|c|c|c|}
\hline \multirow{3}{*}{ Source of variation } & \multirow{3}{*}{$\begin{array}{l}\text { Degree } \\
\text { of } \\
\text { freedom } \\
\text { (d.f) }\end{array}$} & \multicolumn{6}{|c|}{ Variables } \\
\hline & & \multicolumn{2}{|c|}{$\operatorname{FRS}(\%)^{\mathrm{a}}$} & \multicolumn{2}{|c|}{$r$-value ${ }^{b}$} & \multicolumn{2}{|c|}{ AUDPC ${ }^{c}$} \\
\hline & & M.S. & F.value & Ms. & F.value & MS. & F.value \\
\hline Replicates (R) & 6 & 36.76 & 1.08 & 0.0001 & 1.51 & 1250.07 & 0.93 \\
\hline Variety (V) & 6 & 7333.78 & $835.32^{* *}$ & 0.0527 & $134.12^{* *}$ & 162019.53 & $120.42^{* *}$ \\
\hline Environment (E) & 1 & 750.45 & $22.09^{* *}$ & 0.0124 & $152.23^{* *}$ & 123845.14 & $92.06^{* *}$ \\
\hline$V \times E$ & 6 & 8.78 & $0.26^{\mathrm{NS}}$ & 0.0004 & $4.82^{* *}$ & 9649.64 & $7.17^{* *}$ \\
\hline Error & 36 & 33.98 & & 0.0001 & & 1345.21 & \\
\hline
\end{tabular}

a- FRS (\%): Final rust severity (\%).

b- $r$-value : Rate of disease increase.

c-AUDPC: Area under disease progress curve.

\section{RESULTS}

The present study was carried out to characterize partial resistance (PR) to leaf rust (Puccinia triticina) in Sids-1, Sids-12, Giza 168, Sakha 94, Sakha 95, Gemmeiza 7, and Giza 139 Egyptian wheat varieties. The ability of the tested cultivars to slowdown the development of leaf rust infection was estimated and considered as adult plant resistance ( APR ) or field resistance .

The seven Egyptian wheat cultivars including the highly susceptible Giza 139, as a check variety, were tested under field conditions at El-Nubaria location (hot spot), in two successive seasons , 2009/010 and 2010/2011. The obtained data indicated that more leaf rust epidemic was recorded in the first season (2009/010) than in the second season (2010/011). The field observations also showed that the onset of leaf rust disease in the first season was one week earlier than that in the second season (Table, 2). 
The level of partial resistance (PR) to leaf rust was determined for each variety tested, by estimating the three epidemiological parameters.as final rust severity (FRS\%), rate of disease increase ( $r$-value) and area under disease progress curve (AUDPC), under disease stress, under field conditions, during the two seasons of the study.

\section{A. Final rust severity (FRS\%):}

In 2009/2010 the wheat cultivars., Sids1- and Gemmeiza-7, as well as the check variety Giza 139 showed the lowest levels of field resistance to leaf rust infection, in comparison with the other. cultivars under study. Because of the relatively high epidemic of leaf rust during this season, the final rust severity (FRS\%) reached its maximum level $(96.5 \%)$ in the highly susceptible variety, Giza 139 . It was also of relatively high incidence on Sids-1 (82.5\%) and Gemmeiza -7 (70\%), respectively (Table, 2). The cultivars ., Giza 168, Sakha 95, Sids-12 and Sakha 94,on the other hand, exhibited adequate and high levels of APR to leaf rust infection under the same filed conditions. They showed lower estimates of FRS as $12.5 \%, 25.5 \%$, $27.5 \%$ and $35 \%$, respectively (Table, 2 ).

Due to the changes in environmental conditions from one year to another, leaf rust epidemic was found to be less severe in its magnitude during the second growing season (2010/011). The three cultivars., Giza 139 (check), Sids-1 and Gemmeiza-7, showed relatively high estimates of FRS, but with lower values $88 \%$, $75 \%$ and $65 \%$, for these cultivars., respectively (Table,2). While Giza 168, Sakha 95, Sids-12 and Sakha 94, displayed the highest resistance response and satisfactory level of adult plant resistance, under the stress of field conditions at El-Nubaria. They, concomitantly, showed the least FRS values, during that season being $10.25 \%$, $17.5 \%, 22.5 \%$ and $30 \%$, respectively (Table, 2 ). 
Table 2. Final rust severity (FRS\%), rate of disease increase ( $r$-value) and area under disease progress curve (AUDPC) for spread of leaf rust (Puccinia triticina) on leaves of seven Egyptian wheat varieties, under field conditions of El-Nubaria Agric. Res. Sta. during 2009/010 and 2010/011 growing seasons.

\begin{tabular}{|c|c|c|c|c|c|c|c|c|c|c|}
\hline \multirow[b]{2}{*}{ No. } & \multirow[b]{2}{*}{$\begin{array}{c}\text { Wheat } \\
\text { Varieties }\end{array}$} & \multicolumn{3}{|c|}{ Final rust severity $(\mathrm{RFS} \%)^{\mathrm{a}}$} & \multicolumn{3}{|c|}{ Rate of disease increase $(r \text {-value })^{b}$} & \multicolumn{3}{|c|}{ Area under disease progress curve (AUDPC) } \\
\hline & & $\begin{array}{c}2009 / 010 \\
\text { growing } \\
\text { season }\end{array}$ & $\begin{array}{c}\text { 2010/011 } \\
\text { growing } \\
\text { season }\end{array}$ & Mean & $\begin{array}{c}\text { 2009/010 } \\
\text { growing } \\
\text { season }\end{array}$ & $\begin{array}{c}\text { 2010/011 } \\
\text { growing } \\
\text { season }\end{array}$ & Mean & $\begin{array}{c}2009 / 010 \\
\text { growing } \\
\text { season }\end{array}$ & $\begin{array}{c}2010 / 011 \\
\text { growing } \\
\text { season }\end{array}$ & Mean \\
\hline 1 & Sids -1 & 82.50 & 75.00 & 78.75 & 0.2475 & 0.1910 & 0.2193 & 1279.25 & 1118.25 & 1198.75 \\
\hline 2 & Sids-12 & 27.20 & 22.50 & 25.00 & 0.1196 & 0.0832 & 0.1014 & 255.50 & 252.00 & 253.75 \\
\hline 3 & Giza 168 & 12.50 & 10.25 & 11.38 & 0.0634 & 0.0368 & 0.0501 & 159.25 & 114.63 & 136.94 \\
\hline 4 & Sakha 94 & 35.00 & 30.00 & 32.50 & 0.1008 & 0.0789 & 0.0899 & 296.63 & 258.13 & 277.38 \\
\hline 5 & Sakha 95 & 25.50 & 17.50 & 21.50 & 0.0769 & 0.0606 & 0.0687 & 234.50 & 161.00 & 197.75 \\
\hline 6 & Germmeiza-7 & 70.00 & 65.00 & 67.50 & 0.1815 & 0.1642 & 0.1728 & 1181.25 & 936.25 & 1058.75 \\
\hline 7 & Giza 139 "check" & 96.50 & 88.00 & 92.25 & 0.2796 & 0.2459 & 0.2628 & 1459.50 & 1247.75 & 1353.63 \\
\hline \multicolumn{2}{|r|}{ Mean } & 49.93 & 44.04 & - & 0.1528 & 0.1229 & - & 712.25 & 594.88 & - \\
\hline \multicolumn{2}{|c|}{ - L.S.D. of varities } & 8.93 & 8.38 & 5.89 & 0.0144 & 0.0124 & 0.0091 & 55.14 & 53.73 & 37.06 \\
\hline \multicolumn{2}{|c|}{$(\mathrm{V})$} & 12.23 & 11.48 & 7.88 & 0.0197 & 0.0169 & 0.0122 & 75.54 & 73.74 & 49.59 \\
\hline \multicolumn{2}{|c|}{ - L.S.D. of environments $5 \%$} & \multicolumn{3}{|c|}{3.15} & \multicolumn{3}{|c|}{0.0054} & \multicolumn{3}{|c|}{19.81} \\
\hline \multicolumn{2}{|c|}{$(E)$} & \multicolumn{3}{|c|}{4.21} & \multicolumn{3}{|c|}{0.0072} & \multicolumn{3}{|c|}{26.51} \\
\hline \multicolumn{2}{|c|}{ - L.S.D. of interaction $5 \%$} & \multicolumn{3}{|c|}{$8.33 \mathrm{NS}$} & \multicolumn{3}{|c|}{1.0143} & \multicolumn{3}{|c|}{52.41} \\
\hline \multicolumn{2}{|c|}{$(V \times E)$} & \multicolumn{3}{|c|}{11.15} & \multicolumn{3}{|c|}{0.0191} & \multicolumn{3}{|c|}{70.13} \\
\hline
\end{tabular}

a) Final rust severity (FRS\%): was recorded as outlined by Das et al.,1993, b) Rate of disease increase ( $r$-value) was calculated using an equation of Vander Plank, 1963, c) Area under disease progress curve (AUDPC), according to an equation of Pandey et al., 1989. 
Due to the insignificant interaction between varieties and environment $(V \times E)$. L.S.D. was used to compare difference between general means of varieties over the two years. Statistical analysis of combined data over the two years confirmed that highly significant differences were obtained between the FRS means of any pair of the different wheat cvs., under study. Only the difference between general means of the two partially resistant cvs., Sids-12 and Sakha 94, was insignificant.

\section{B. Rate of disease increase (r-value):}

In general, rust developed more slowly and increased at relatively lower rates ( $r$-values) on the leaves of all tested cultivars., during the second growing season (2010/011), compared to the previous one (2009/010).

In the first season (2009/010), the wheat cultivars, Giza 139, Sids-1 and Germmeiza-7, have rusted faster and with higher rates of disease development than others, under El-Nubaria field conditions. These cultivars exhibited higher rates of leaf rust increase (r-value), during this growing season, being. 0.280, 0.248 and 0.182 , respectively (Table, 2 ). On the other hand rust developed more slowly and at lower rates of disease increase (r-value) in the four cultivars., Giza 168, Sakha 95, Sakha 94 and Sids -12 , under the same field conditions. They consistently exhibited lower rates of rust increase, $r$-values being $0.063,0.077,0.101$ and 0.120 , respectively (Table, 2 ). So, they were classified as partial resistant group, in comparison with the highly susceptible varieties.

In the second season (2010/011) it was, generally, found that leaf rust developed at a relatively lower rates on the wheat cultivars t., Giza 168, Sakha 95, Sakha 94 and Sids-12. They revealed lower rates of rust development during that season, 0.037, 0.061, 0.079 and 0.083, respectively. Therefore they were characterized as PR varieties (Table, 2). Other varieties including the three cultivars., Giza 139 (check), Sids-1 and Gemmeiza 7, showed high estimates of r-values i.e. $0.250,0.191$ and 0.164 , respectively, and were classified as fast-rusting or highly susceptible (Table, 2).

Because of the high significance of the interaction between varieties and environment $(\mathrm{Vx} E)$, the values of L.S.D were used to compare the differences in means of any pair of the tested varieties within each year. In general,a highly significant difference was found in most comparisons between any pair of the tested varieties, especially if they were not in the same variety group (Table, 2 ).

\section{C-Area under disease progress curve (AUDPC):}

Area under disease progress curve (AUDPC), as a convenient and a good reliable criterion of the PR character, was also estimated for the tested varieties (Table, 2). 
Different values of AUDPC were presented for the tested wheat varieties during the two years of the study, as affected by the slight changes in environmental conditions, in each growing season. However, field conditions observed in the first season (2009/2010) were apparently more favorable for disease onset and development, compared to those in the latter one (2010/2011). Thus, higher estimates of AUDPC, were recorded in the highly susceptible cultivars, during the first growing season. Data obtained in the second season (2010/011) showed similar trends, but at lower values (Table, 2).

Depending on the obtained data and on the basis of AUDPC estimates, over the two years, the tested wheat varieties may be classified into two main groups. The first group included wheat cultivars with the lowest AUDPC estimates (less than 300) i.e. Giza 168 (159.25 \&114.63), Sakha 95 (234.5 \& 161.0), Sids-12 (255.5 \& 252.0) and Sakha 94 (296.63 \& 258.13) in 2009/010 and 2010/011 growing seasons, respectively (Table, 2 ). These cultivars were, therefore, designated as the partially resistant (PR) ones., since they displayed the highest and satisfactory levels of APR or field resistance, under the stress of leaf rust infection, through the two growing seasons of the study.

The second group of cultivars, on the other hand, included the highly susceptible cultivars, Gemmeiza-7, Sids-1 as well as the check variety, Giza 139., They revealed the lowest levels of APR to leaf rust infections under field conditions during the two growing seasons of the study. They showed the highest estimates of AUDPC, $1181.25,1279.25$ and 1459.50, in 2009/2010, and936.2, 1118.25, and 1247.75 in 2010/2011 growing seasons, respectively (Table, 2). Accordingly, it has been, reasonably, suggested that this group of varieties, could be classified as the fastrusting variety group.

Because of the high significance of interaction between varieties and environment $(\mathrm{V} \times \mathrm{E})$, the L.S.D values were, therefore, used to compare between the differences in AUDPC means of any two varieties within each envrioment (year). In general, differences of AUDPC values varied significantly in all comparisons. Meanwhile, the difference was more pronounced and of very high significance, if the two varieties compared, were in different groups.

\section{D- Effect of environment, genotypes and their interaction on the variation of the three epidemiological parameters:}

Relative contribution, expressed as the percentage of mean square of the explained model variation, was estimated for each parameter under study i.e. FRS (\%), r.value and AUDPC. This was carried out in order to determine the effect of 
environment (years), genotypes (varieties) and their interaction in the variation of these parameters. (Table, 3).

Table 3. Relative contribution of environment (years), genotypes (varieties) and their interaction to the variation in three partial resistance parameters, (FRS\%), $r$ value and AUDPC.

\begin{tabular}{|c|c|c|c|}
\hline \multirow{2}{*}{$\begin{array}{c}\text { Source } \\
\text { of variation }\end{array}$} & \multicolumn{3}{|c|}{ Relative contribution to a variation of } \\
\hline & FRS $(\%)^{\mathrm{a}}$ & $r$-value ${ }^{b}$ & AUDPC $^{\mathrm{C}}$ \\
\hline Environment (year , E) & $1.67 \%$ & $3.74 \%$ & $1.83 \%$ \\
\hline Genotypes (varieties , V) & $97.73 \%$ & $95.53 \%$ & $97.36 \%$ \\
\hline Interaction $(\mathrm{E} \times \mathrm{V})$ & $0.12 \%$ & $0.73 \%$ & $0.81 \%$ \\
\hline
\end{tabular}

a) FRS (\%): Final rust severity (\%)

b) r-value : Rate of disease increase.

c) AUDPC: Area under disease progress curve.

It is evident that , more than $95 \%$ of the detected variation in the three parameters under study, were attributed to the genotypic structure of wheat varieties. Whereas little or low relative contribution of the environment to the variation of the three disease parameters was estimated. However, the genetic structure of the tested varieties relatively contributed by $95.53 \%, 97.36 \%$ and $97.73 \%$ to the three rust parameters, r-value, AUDPC and FRS (\%), respectively (Table, 3$)$. Therefore, it seems reasonable to suggest that the variation found in adult plant response to leaf rust infection between PR varieties and susceptible ones, was consistently attributed to there genetic structure rather than the changes in environmental conditions from year to year.

\section{E- Genetic components of variance:}

The two genetic parameters i.e heritability in the broad sense $\left(\mathrm{h}^{2}\right)$ and genetic advance expected from selection, were computed for the three PR epidemiological parameters i.e. FRS (\%), r-value and AUDPC (Table, 4).

High heritability values (up to $99 \%$ ) were obtained for each parameter under study. It was $99.88 \%$ for AUDPC, $99.25 \%$ for FRS (\%) and $99.17 \%$ for r-value. The high values of heritability, during the two seasons of the study, indicated that most of the phenotypic variation in these PR components, was mainly due to the genetic effects. Also, these variations were less affected by changes in environmental conditions, through the two years of the study. 
Table 4. Heritability in its broad sense $\left(h^{2}\right)$ and genetic advance expected from selection (GA) for final rust severity (FRS\%), rate of disease increase ( $r$ value) and area under disease progress curve (AUDPC) variables for seven wheat cultivars tested for their partial resistance to leaf rust at El-Nubaria Agric. Res. Stn.

\begin{tabular}{|c|c|c|c|}
\hline \multirow{2}{*}{\begin{tabular}{c} 
Genetic parameter \\
\cline { 2 - 4 }
\end{tabular}} & FRS (\%) & Variables $^{*}$ (AUDPC) $^{* *}$ & (r-values) $^{* *}$ \\
\hline $\begin{array}{c}\text { Heritability in broad } \\
\text { sense }\left(\mathrm{h}^{2}\right)\end{array}$ & $99.25 \%$ & $99.88 \%$ & $99.17 \%$ \\
\hline Genetic advance (GA). & 17.62 & 46.95 & 22.02 \\
\hline
\end{tabular}

* FRS (\%): Final rust severity (\%).

**AUDPC: Area under disease progress curve

*** r-value : Rate of disease increase.

In addition ,the genetic advance expected from selection (GA), based on AUDPC values were relatively of high value (46.95). While those based on r-value and FRS (\%) were of lower values, 22.02 and 17.62, respectively (Table, 4). Therefore, AUDPC was considered a promising and more meaningful field characteristic for selecting partially resistance (PR) genotypes to leaf rust infection.

\section{DISCUSSION}

Partial resistance (PR) to wheat leaf rust (Puccinia triticina) has been early characterized by a decreased rate of an epidemic development and/or build-up in the field, despite a susceptible infection type or irrespective of a compatible hostpathogen interaction (Broers, 1989 and Niks et al., 2011). Such resistance was also identified, from other point of view, as a polygenic form of resistance (Boulot and Gad-Alla, 2007), or a race-non-specific (general) resistance (Kuhn et al., 1978). So, it has a permanent effect against a broad spectrum of the prevalent races or sudden race changes of leaf rust pathogen (Midaner and Korzun, 2012). It presumably, lasts longer and remains effective over a wide range of environmental conditions for many years. It is therefore considered to be more durable than other forms of resistance (Kuhn et al., 1978, Broers and Parlevliet, 1989 and Boulot, 2007).

In the last four decades, most of the locally produced wheat cultivars have been developed as having field resistant or adult plant resistant (APR) to leaf rust. Many of them served in the commercial fields without any dramatic changes in their level of leaf rust resistance and yield potentiality (Nazim et al., 1992 and Boulot, 2007). The first two partially resistant cultivars produced in Egypt were Giza 155 and 
Giza 156, which proved to have the ability to slowdown the development and progress of leaf rust infection, under the Egyptian field conditions. The new released wheat varieties, derived from these two cultivars and others possessing, so far, the same type of resistance, as they also characterized by their susceptibility to most leaf rust races at seedling stage, but showed an adequate and acceptable levels of APR, under field conditions (Nazim et al., 1990, Negm, 2004 and Boulot, 2007). Out of these cultivars, seven were tested in the present study at different field and greenhouse conditions during the two successive seasons, in order to provide an accurate characterization of this type of resistance, as expressed by these cultivars.

Under field conditions, at El-Nubaria lacation (hot spot of leaf rust), adult plant resistance (APR) was experimentally measured and characterized by using three epidemiological parameters, final rust severity (FRS\%), rate of disease increase ( $r$ value) and area under disease progress curve (AUDPC). These parameters were found to be higher in magnitude for wheat cultivars., Giza 168, Sakha 94, Sakha 95 and sids 12, than in the highly susceptible ones., Sids1, Gemmeiza 7 and Giza 139 (check), during 2009/2010 and $2010 / 2011$ growing seasons. During the two years of the study, final rust severity (FRS\%) was found to be of lower values (ranged from 10.25 to $35 \%$ ) on the APR cultivars. In contrast, the highly susceptible cultivars. exhibited the lowest levels of APR to leaf rust infection and were severely rusted and showed the highest estimates of FRS (ranged from 65\% to 96.5\%), under the same field conditions in both growing seasons of the study. Consequently, it was concluded that, each of the wheat cultivars., Giza 168, Sakha 94, Sakha 95 and sids 12, had the potential to decrease the amount of leaf rust infection during an epidemic, in both years of the study.

It was possible to distinguish the partially resistant (PR) cultivars from the susceptible ones, by their capacity to decrease the rate of disease increase, either in time, in space or both, under field conditions in the two years of the study. Whereas PR cultivars were substantially characterized by lower rates of disease increase ( $r$ values), relative to the susceptible ones, when subjected to the same pathogen populations and under the same field conditions of the current study. However, difference in r-values between any two wheat varieties tested during an epidemic was mainly due to two limiting factors. The first is the disease severity (\%) in each, and the second is the spread of the fungus propagules, or the time of disease increase (Van der Plank, 1963 and Gregory, 1968). Out of the tested cultivars, four cultivars proved to possess the capacity to slowdown the disease onset and development during an epidemic in both years of the study, resulting in lower rates of disease increase. Inversely, the highly susceptible cvs., Sids 1 and Gemmeiza7, as well as the 
check variety, Giza 139, have been rapidly rusted with higher and faster rates of disease increase under the same environmental conditions during the two years of the study.

To gain a more detailed speculation on the variation of PR to leaf rust, and so far, more accurate characterization of this type of resistance in the tested cultivars, AUDPC was used. However AUDPC as a good estimator of PR resistance was widely applied and used by many investigators. All of them mentioned that AUDPC was a reliable and more convenient estimator of APR than any other parameter. Because it represents both the amount of rust infection and the rate at which the disease or pathogen has increased during an epidemic (Sayre et al., 1998, Nazim et al., 1990, Lal. Ahamed et al., 2004 and Boulot, 2007). The wide application of AUDPC for estimating PR , rather than other epidemiological parameters, is due to enclosure of all factors that influence or affect the disease development (Pandey et al., 1989, Das et al., 1993 and Lal Ahamed et al., 2004). According to the obtained results relevant to AUDPC estimates, the tested cultivars could be substantially classified into two main variety groups. The first group includes the wheat cultivars, Giza 168, Sakha 94, Sakha 95 and sids-12, that continued to display high levels of adult plant resistance under field conditions during the two growing seasons of the study. These cultivars showed, however, the lowest estimates of AUDPC, less than 300. These cultivars were, therefore, characterized as a partially resistant (PR) group of cultivars. Whereas, the second group includes the highly susceptible cultivars i.e. Sids-1, Gemmeiza -7 and Giza 139 (check variety). This group of cultivars were severely and rapidly rusted during the two seasons considered. They consequently, showed the highest AUDPC values (more than 900). In the same time, they exhibited the lowest levels of adult plant resistance (APR). Hence, they could be classified as the highly susceptible or fast-rusting variety group.

Studies carried out under the Egyptian field conditions by Nazim et al. (1983), Nazim et al.(1990), Boulot (2007) and Negm (2004) have been in accordance with the results obtained herein. These studies came to the conclusion that, some of the local wheat cultivars have an adequate level of field resistance or adult plant resistance (APR) to leaf rust, regardless of their seedling reactions in terms of infection types, and many of them served in agriculture for many years, showing high levels of PR during their vast cultivation under Egyptian field conditions.

Relatively high percentages of genotype contribution to the variation of the three epidemiological parameters, FRS (\%), r-value and AUDPC, were found. It was found that more than $97 \%$ of the differences in leaf rust response of the tested cultivars., were mainly due to the genetic components of these cultivars. Meanwhile, 
the percentage of the relative contribution of the environment (years) was found to be very low (less than $4 \%$ ). Therefore, the expression of partial resistance (PR) was slightly affected by the changes in environmental conditions from one year to another. Hence, the expression of this type of resistance remains stable under various environmental conditions favorable to the pathogen infection and spread. Also, it remained effective against almost all the prevalent pathogen races (Broers and Parlevliet, 1989, Singh et al., 2005 and Boulot, 2007). This issue was also, confirmed by the high heritability estimates obtained in each year of the present study with the above three epidemiological parameters (up to 99\%). These high estimates of heritability in its broad sense $\left(h^{2}\right)$ indicated that most of the phenotypic variation was substantially due to the genetic effects. The high heritability estimates of these parameters, clearly demonstrated that any of these parameters could be used as a good criterion for evaluating and selecting PR genotypes, under field conditions. Consequently, rapid and considerable progress in breeding for PR to leaf rust would be expected in current breeding programs, using these parameters. (Ageez and Boulot, 1999, Navabi et al., 2003, Singh et al., 2005 and Boulot and Gad-Alla, 2007).

\section{REFERENCES}

1. Ageez, A.A. and O.A. Boulot. 1999. Quantitative determination of the gene action of leaf rust resistance in a 7-parents diallel cross of wheat. Egypt. J. of Appl. Sci., 14 (6): 216-226.

2. Boulot, O.A., 2007. Durable resistance for leaf rust in twelve Egyptian wheat varieties. Egypt. J. of Appl. Sci., 22 (7) : 40-60.

3. Boulot, O.A. and A.M. Gad-Alla, 2007. Inheritance of adult-plant resistance to leaf rust in five Egyptian bread wheat cultivars. J. Agric. Sci. Mansoura Univ., 32 (6): 4355-4368.

4. Broers, L.H.M., 1989. Partial resistance to wheat leaf rust in 18 spring wheat cultivars. Euphytica, 44: 247-258.

5. Broers, L.H.M. and J.E. Parlevliet, 1989. Environmental stability of partial resistance in spring wheat to wheat leaf rust. Euphytica, 44: 241-245.

6. Das, M.K., S.Rajaram, W.E.Kronstad, C.C. Mundt and R.P. Singh, 1993. Association and genetics of three components of slow rusting in leaf rust of wheat. Euphytica, 68: 99-109.

7. Gregory, P.H., 1968. Interpreting plant disease dispersal gradients. Annu. Rev. Phytopathol., 6: 189-212.

8. Kuhn, R.C., H.W. Ohm and G.E. Shaner, 1978. Slow leaf-rusting resistance in wheat against twenty two isolates of Puccinia triticina. Phytopathology, 68: 651656. 
9. Lal Ahamed, M., S.S. Singh, J.B. Sharma and R.B. Ram, 2004. Evaluation of inheritance to leaf rust in wheat using area under disease progress curve. Hereditas, 141: 323-327.

10. Miedaner, T. and V. Korzun, 2012. Marker-assisted selection for disease resistance in wheat and barley breeding. Phytopathology, 102: 560-566.

11. Navabi, A., R.P. Singh, J.P. Tewari and K.G. Briggs, 2003. Genetic analysis of adult-plant resistance to leaf rust in five spring wheat genotypes. Plant Dis., 87: 1522-1529.

12. Nazim, M.S., A.A. El-Shehidi, Y.A. Abdou and Y.H. El-Daoudi, 1983. Yield losses caused by leaf rust on four wheat cultivars under epiphytotic levels. Proc. 5th Conf. Microbiol., Cairo, Egypt: 17-27.

13. Nazim, M.S., M.Z. El-Shanawani, Z. El-Shennawy and O.A. Boulot, 1990. Partial resistance to leaf rust in some Egyptian wheat varieties. Proc. $6^{\text {th }}$ Cong. Egypt. Phytopathol. Soc., Part 1, 77-97.

14. Negm, S.A., 2004. Partial resistance to leaf rust in some Egyptian wheat varieties. Ph.D. Thesis, Fac. of Agric., El-Minufiya University, Egypt, 180pp.

15. Niks, R.E., J.E. Parlevliet, P. Lindhout and Y. Bai, 2011. Breeding crops with resistance to diseases and pests. Wagening Academic Publishers, The Netherlands.

16. Pandey, H.N., T.C.M. Menon and M.V. Rao, 1989. A simple formula for calculating area under disease progress curve. Rachis Vol. 8, No.2: 38-39.

17. Parlevliet, J. E., 1976. Evaluation of the concept of horizontal resistance in the barley Puccinia hordei host-pathogen relationship. Phytopathology, 66: 494-497.

18. Peterson, R.F., A.B. Campbell and A.E. Hannah, 1948. A diagrammatic scale for estimating rust intensity on leaves and stems of cereals. Can. J. Res., 60: 496500.

19. Sayre, K.D., R.P.Singh, J. Huerta-Espino and S. Rajaram, 1998. Genetic progress in reducing losses to leaf rust in CIMMYT-derived Mexican spring wheat cultivars. Crop Sci., 38: 654-659.

20. Singh, R.P., J. Huerta-Espino and H.M. William, 2005. Genetics and breeding for durable resistance to leaf and Stripe rusts in wheat. Turk. J. Agric., 29: 121-127.

21. Snedecor, G.W. and W.G. Cochran, 1967. Statistical Methods. $6^{\text {th }}$ ed. Towa State Univ. Press, USA. 593pp.

22. Van der Plank, J.E., 1963. Plant diseases: Epidemics and control. Academic Press, New York, 349p. 


\title{
المقاومة الجزئية لمرض صدأ أوراق القمح "باكسينيا تريتسينا" فى مصر \\ أ) تقييم سبعة اصناف قمح مصريه للمقاومه الجزئيه \\ لمرض صدأ الاوراق تحت الظروف الحقليه
}

\author{
أسامة أحمد بعلط، على عبد الهادى على \\ معرذ بحوث أمراض النبات - مركز البحوث الزراعية - الجبزة - مصر
}

يعد مرض صدأ الأوراق من أكثر الأمر اض التى تصيب المجموع الخضرى لنباتات القمح

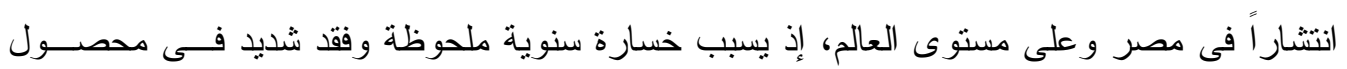
الحبوب للأصناف القابلة للإصابة بالمرض، وخاصة فى المناطق الثمالية بمصر ـ.ومن أهم التحديات

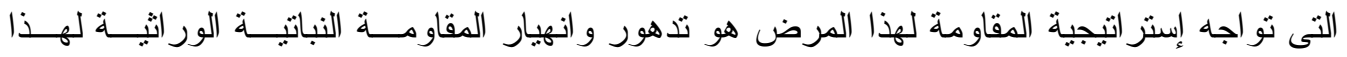

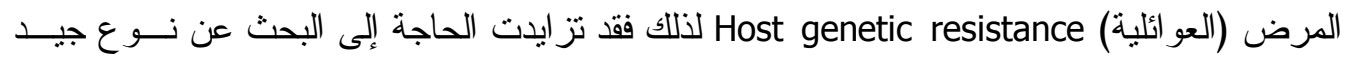

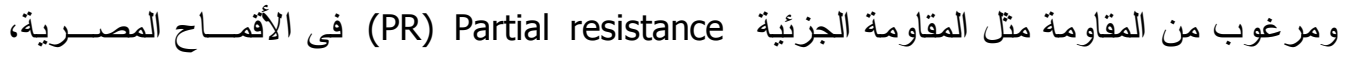
و التىى تتميز بكونها أكثر قدرة على البقاء (ثابته) أو طويلة الأمد "'More durable" عن غير ها مــن أنو اع المقاومة النباتية المعروفة.

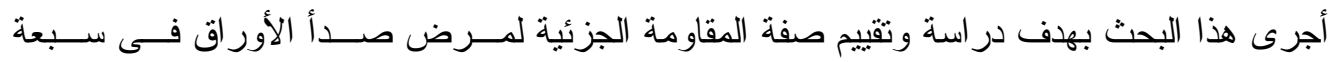
أصناف من الأقماح المصرية، وذللك بتقدير مستوى هذه المقاومة للنباتات البالغة لتلك الأصناف تحت

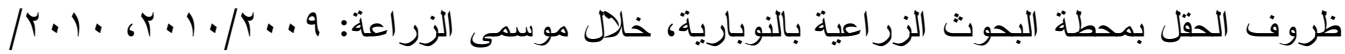
$.5+11$

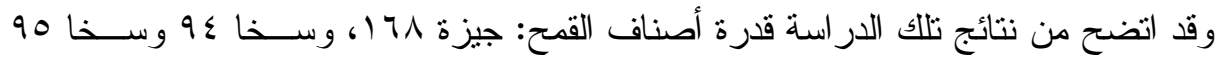
وسدس r ا على تقليل سرعة تزايد وتطور المرض، وبالتالى إظهار مستويات منخفضة من الإصابة

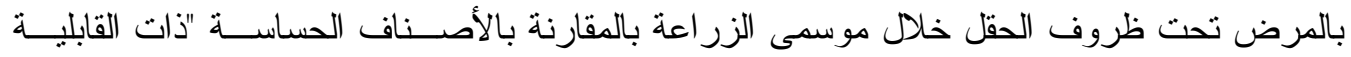
العالية للإصابة بالمرض"، وفى نفس الوقت فقد تميزت تلك الأصناف بإظهار مستويات عالية ومقبولة

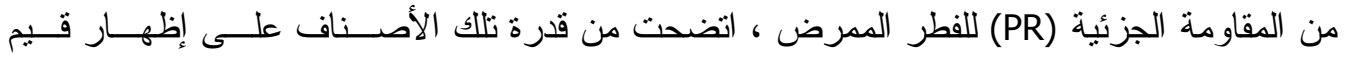
منخفضة من النسبة المئوية لثدة المرض النهائية "FRS\%"، حيث قد تراوحت تلأك النسبه فقط ما بين

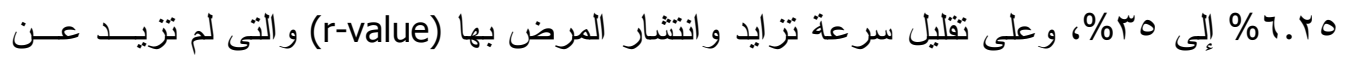

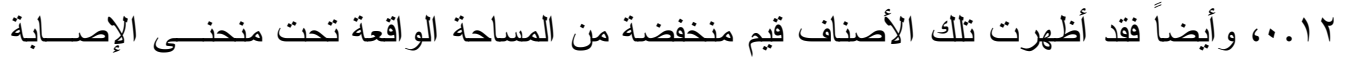

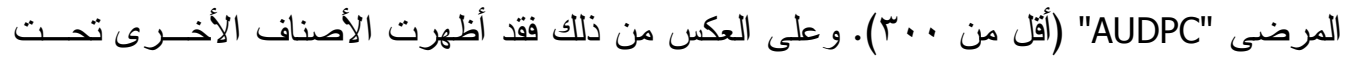

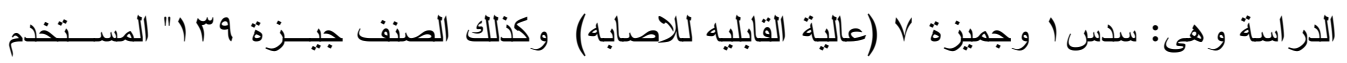

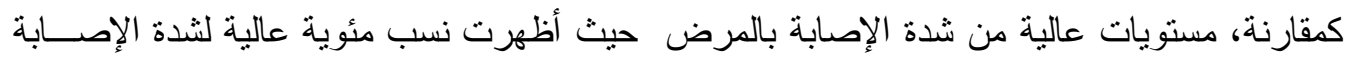

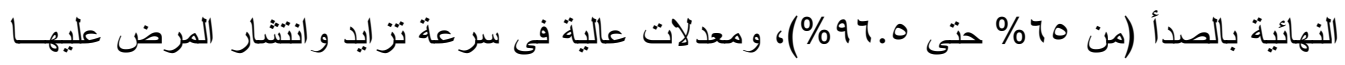

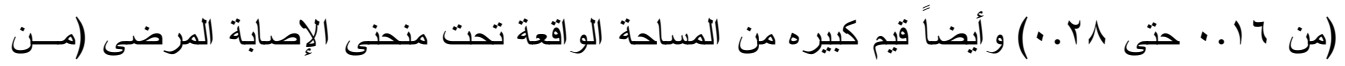




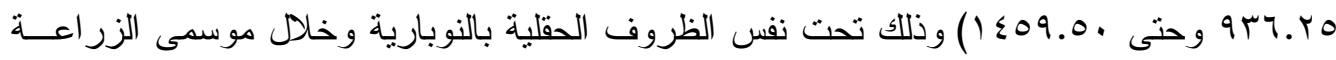
تحت الدر اسة. وبناء على النتائج المتحصل عليها فى ذلك البحث فانــهـ يمكـن اجـر اء التقــدير الكمـى

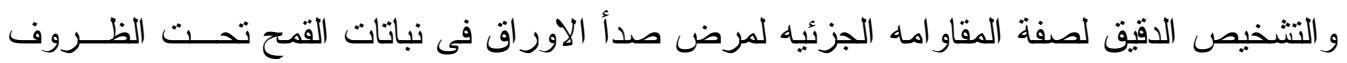

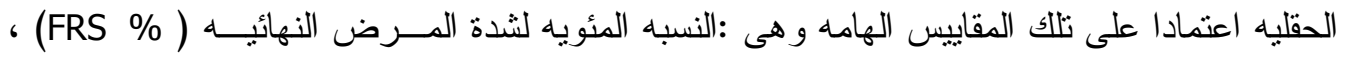
وسر عة تز ايد المرض (r-value) و المساحه الو اقعه تحت منحنى الاصـابه المرضى (AUDPC) حيــث

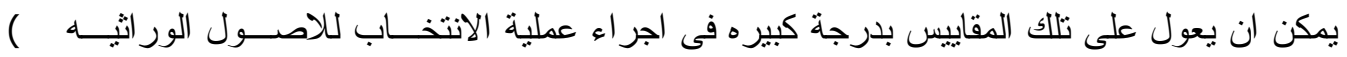
genotypes) من خلال بر امج التربيه للمقاومه لأمر اض الاصداء عموما ولصدأ الاور اق على وجه الخصوص. 